\title{
Evaluating Effectiveness of a Marine Protected Area Network in West Hawai'i to Increase Productivity of an Aquarium Fishery ${ }^{1}$
}

\author{
Brian N. Tissot, ${ }^{2}$ William f. Walsh, ${ }^{3}$ and Leon E. Hallacher ${ }^{4}$
}

\begin{abstract}
A network of nine Fish Replenishment Areas (FRAs) was established in West Hawai' $\mathrm{i}$ in 2000 in response to declines of reef fishes taken by aquarium collectors. In 1999, we established 23 study sites in FRAs, areas open to collectors, and reference areas (existing protected areas) to collect data both before and after the closure of the FRA network in 2000. To date we have conducted 23 bimonthly fish surveys as well as surveys of the benthic habitats of all sites. Baseline surveys, done before FRA closure, document significant effects of aquarium collector harvesting on selected fishes. On average, aquarium fishes were $26 \%$ less abundant in newly established FRAs (formerly open) than in adjacent reference areas. Analysis of postclosure surveys in 2000-2002 using a Before-After-Control-Impact procedure provided evidence of a significant increase in two of the 10 species examined, including the yellow tang (Zebrasoma flavescens), the most collected aquarium fish in Hawai' $\mathrm{i}$. The recovery of yellow tangs to preexploitation levels in the FRAs was probably due to the high number of newly recruited fishes observed in 2001-2002. Large recruitment events are rare in West Hawai'i but are likely to be an important factor determining the effectiveness of Marine Protected Areas to help replenish depleted fish populations.
\end{abstract}

CoRal ReEFs ARE diverse and productive biological communities that provide important natural resources in tropical areas. However, reefs in many parts of the world currently are being threatened with a wide variety of anthropogenic disturbances (Richmond 1993). On the island of Hawai' $i$, excessive harvesting by the aquarium trade is a major source of overfishing that warrants improved resource management (Grigg 1997, Clark and Gulko

1 This research was supported by grants from the Hawai'i Coral Reef Initiative Research Program in 19992003 and from the Division of Aquatic Resources in 2002. Manuscript accepted 27 May 2003.

${ }^{2}$ Washington State University-Vancouver, 14204 NE Salmon Creek Avenue, Vancouver, Washington 98686 (E-mail: tissot@vancouver.wsu.edu).

${ }^{3}$ Division of Aquatic Resources, 88-1610 Māmalahoa Highway, Captain Cook, Hawai'i 96704 (E-mail: darkona @interpac.net).

${ }^{4}$ Department of Biology, University of Hawai'i at Hilo, 200 West Kāwili Street, Hilo, Hawai'i 96720 (E-mail: leonh@hawaii.edu).

Pacific Science (2004), vol. 58, no. 2:175-188

(C) 2004 by University of Hawai'i Press
1999, Tissot and Hallacher 2003). This project addresses the implementation and evaluation of a fishery management plan on the island of Hawai' $i$ (Act 306 of 1998) focused on aquarium fish collecting using a network of Marine Protected Areas (MPAs).

MPAs are currently of wide national and international interest (Allison et al. 1998, Bohnsack 1998, Murray et al. 1999). However, very few studies of MPAs are replicated (e.g., have more than one protected area) or have statistically rigorous monitoring programs with data collected both before and after closure (Murray et al. 1999). This project represents a unique opportunity both to investigate the effectiveness of MPAs in fishery management and to provide an assessment of aquarium fish collecting effects on the island of Hawai' $i$ that builds on earlier work (Tissot and Hallacher 2003).

The aquarium collecting industry in $\mathrm{Ha}$ wai'i has had a long, contentious history. As early as 1973, public concern over collecting activities was first addressed by the Hawai' $i$ Division of Aquatic Resources (DAR) by requiring monthly collection reports. However, the industry has been largely unregulated 
since then despite dramatic increases in the number of both issued collecting permits and collected fishes. Further, increases in fish collecting combined with growing public perception of dwindling fish stocks eventually developed into a severe multiple-use conflict between fish collectors and the dive tour industry.

In response to declines in reef fishes due to aquarium collectors, the Hawai' $i$ State Legislature, through Act 306, created the West Hawai'i Regional Fishery Management Area in 1998 to improve management of fishery resources. One of the requirements of Act 306 mandates that DAR declare a minimum of $30 \%$ of the West Hawai'i coastline as Fish Replenishment Areas (FRAs), MPAs where aquarium fish collecting is prohibited. The Act also called for substantive involvement of the community in resource management decisions. In 1998, the West Hawai'i Fisheries Council, a community-based group of individuals, proposed nine FRAs along the West Hawai' $i$ coastline that collectively prohibited aquarium fish collecting along $35 \%$ of the coast when combined with existing protected areas. The proposed management plan received $93 \%$ support at a public hearing, was subsequently approved by the Governor, and the FRAs were officially closed to aquarium collectors on 1 January 2000.

Our principal purpose in this paper is to provide a broad evaluation of the effectiveness of the nine FRAs to increase the productivity of aquarium fishery resources. Specifically, our goals in this paper are (1) to evaluate the general effectiveness of the MPA network by comparing fish abundances among reference, open, and FRA study sites before and after FRA closure; (2) to estimate the effects of aquarium fish collecting both in and outside of FRAs in West Hawai'i; and (3) to generate hypotheses on mechanisms that influence FRA effectiveness. A paper analyzing the effectiveness of individual FRAs will be published elsewhere.

\section{MATERIALS AND METHODS}

Our observational design compared FRA study sites before and after closure with sites that remained open to aquarium fish collecting (open sites) and those that were not subjected to aquarium fish collecting (reference sites). Reference sites included Marine Life Conservation Districts (MLCDs) and Fishery Management Areas (FMAs), both of which prohibit aquarium fish collecting, along with other activities. A total of 23 study sites was selected in early 1999 . The sites were established in six existing reference areas, in eight open areas adjacent to FRAs, and in all nine of the FRAs (Figure 1, Table 1).

Study sites were selected within an area of suitable habitat and depth using a procedure that attempted to minimize among-site habitat variability yet selected unbiased locations within an area. A diver was towed behind a slow-moving vessel in the area of interest (open, FRA, or reference) to search for areas suitable as study sites. Criteria for acceptable sites included a substratum with abundant finger coral (Porites compressa) at 10 - to $18-\mathrm{m}$ depths. Finger coral is an important habitat for juvenile aquarium fishes, particularly the yellow tang, Zebrasoma flavescens, and typically dominates most areas of the West Hawai'i coast at 10 - to $18-\mathrm{m}$ depths except along exposed headlands and on recent lava flows (Grigg and Maragos 1974, Dollar 1982). Within an area of suitable habitat and depth a float with an attached weight was haphazardly thrown off a moving vessel and the oceanside center transect pin was established at the coral colony nearest to the weight on the bottom. Using five additional stainless-steel bolts cemented into the bottom, we established four permanent $25-\mathrm{m}$ transects in an H-shaped pattern at each of the study sites. During field surveys, study sites were located by differential global positioning system (GPS), and the transect lines were deployed between the eyebolts.

\section{Survey Metbods}

We used a quantitative video sampling method to monitor benthic habitats at each study site (Aronson et al. 1994, Carleton and Done 1995). To ensure consistency with other coral reef survey methods used in the state of Hawai' $i$, we developed our design in 


\section{West Hawai'i Regional Fishery Management Area}

$2 \varphi$ $-5$

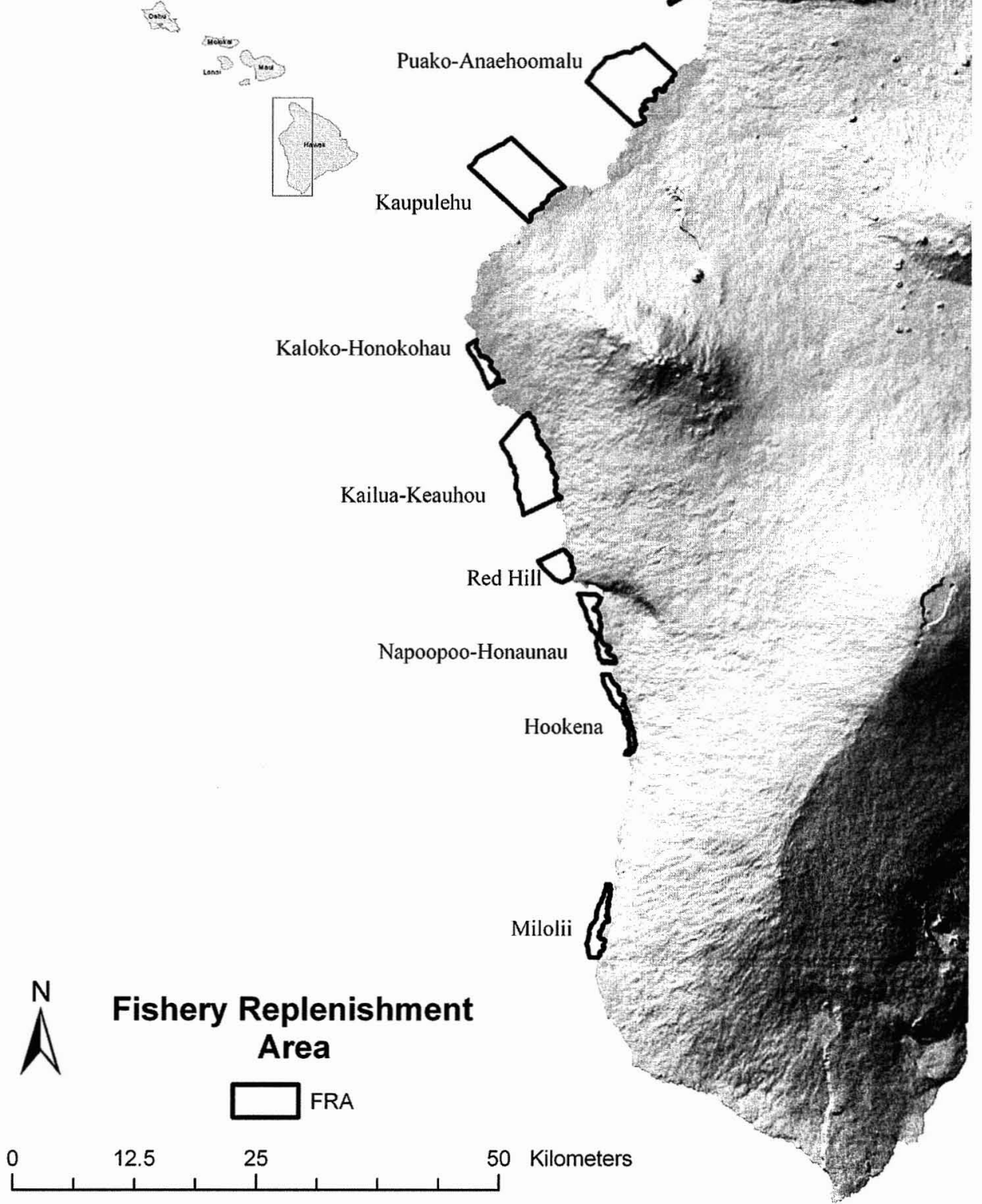

North Kohala

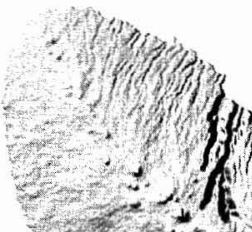

FIGURE 1. Locations of Fishery Replenishment Areas (FRAs) established in the West Hawai'i Regional Fishery Management Area. 
TABLE 1

Descriptions of Study Sites Established in the West Hawai'i Regional Fishery Management Area in Relation to Observational Design Assignments

\begin{tabular}{|c|c|c|c|}
\hline Site & Status $^{a}$ & Protected Activities at Site & $\begin{array}{l}\text { Depth Range } \\
(\mathrm{m})\end{array}$ \\
\hline \multicolumn{4}{|l|}{ North Kohala } \\
\hline 1. Lapakahi & MLCD & $\begin{array}{l}\text { No fishing, taking, or injuring of any type of marine life is } \\
\text { permitted }\end{array}$ & $10-15$ \\
\hline 2. Kamilo & Open & No restrictions & $13-15$ \\
\hline 3. Waiakaîlio Bay & FRA & $\begin{array}{l}\text { No taking of aquatic life for aquarium purposes or to engage } \\
\text { in fish feeding }\end{array}$ & $12-14$ \\
\hline \multicolumn{4}{|l|}{ Puakō-'Anaeho'omalu } \\
\hline 4. Puakō & FMA & Prohibited to possess or use any type of net except throw net & $9-10$ \\
\hline 5. 'Anaeho'omalu & FRA & $\begin{array}{l}\text { No taking of aquatic life for aquarium purposes or to engage } \\
\text { in fish feeding }\end{array}$ & $10-11$ \\
\hline 6. Keawaiki & Open & No restrictions & $11-15$ \\
\hline \multicolumn{4}{|l|}{ Ka'ūpūlehu } \\
\hline 7. Ka'ūpūlehu & FRA & $\begin{array}{l}\text { No taking of aquatic life for aquarium purposes or to engage } \\
\text { in fish feeding }\end{array}$ & 13 \\
\hline 8. Makalawena & Open & No restrictions & $10-11$ \\
\hline \multicolumn{4}{|l|}{ Kaloko-Honokōhau } \\
\hline 9. Wāwāloli Beach & Open & No restrictions & 10 \\
\hline 10. Wāwāloli & FMA & $\begin{array}{l}\text { No taking of aquatic life for aquarium purposes or to engage } \\
\text { in fish feeding, except for 'ôpelu fishing }\end{array}$ & $12-15$ \\
\hline 11. Honokōhau & FRA & $\begin{array}{l}\text { No taking of aquatic life for aquarium purposes or to engage } \\
\text { in fish feeding }\end{array}$ & $12-14$ \\
\hline \multicolumn{4}{|l|}{ Kailua-Keauhou } \\
\hline 13. Papawai & FMA & $\begin{array}{l}\text { No taking of aquatic life for aquarium purposes or to engage } \\
\text { in fish feeding, except for 'ópelu fishing }\end{array}$ & $9-13$ \\
\hline 14. S. Ōneo Bay & FRA & $\begin{array}{l}\text { No taking of aquatic life for aquarium purposes or to engage } \\
\text { in fish feeding }\end{array}$ & $10-14$ \\
\hline \multicolumn{4}{|l|}{ Red Hill } \\
\hline 15. N. Keauhou & FRA & $\begin{array}{l}\text { No taking of aquatic life for aquarium purposes or to engage } \\
\text { in fish feeding }\end{array}$ & $9-12$ \\
\hline 16. Kualanui Point & Open & No restrictions & $9-13$ \\
\hline 17. Red Hill & FMA & $\begin{array}{l}\text { No taking of aquatic life for aquarium purposes or to engage } \\
\text { in fish feeding except for 'opelu fishing }\end{array}$ & $12-15$ \\
\hline \multicolumn{4}{|l|}{ Nāpō'opo'o-Hōnaunau } \\
\hline 18. Keōpuka & Open & No restrictions & $9-14$ \\
\hline 19. Kealakekua Bay & MLCD & $\begin{array}{l}\text { No fishing, taking or injuring of any type of marine life is } \\
\text { permitted }\end{array}$ & $6-11$ \\
\hline 20. Ke'ei & FRA & $\begin{array}{l}\text { No taking of aquatic life for aquarium purposes or to engage } \\
\text { in fish feeding }\end{array}$ & $9-15$ \\
\hline \multicolumn{4}{|l|}{ Ho'okena } \\
\hline 21. Ho'okena (Kalāhiki) & FRA & $\begin{array}{l}\text { No taking of aquatic life for aquarium purposes or to engage } \\
\text { in fish feeding }\end{array}$ & $9-12$ \\
\hline 22. Ho'okena ('Au'au) & Open & No restrictions & $11-15$ \\
\hline \multicolumn{4}{|l|}{ Miloli'i } \\
\hline 23. Miloli'i (Omoka'a) & FRA & $\begin{array}{l}\text { No taking of aquatic life for aquarium purposes or to engage } \\
\text { in fish feeding }\end{array}$ & $10-15$ \\
\hline 24. Miloli'i (Manukā) & Open & No restrictions & $10-15$ \\
\hline
\end{tabular}

a Protection status: MLCD, Marine Life Conservation District; FMA, Fishery Management Area; FRA, Fishery Replenishment Area; Open, areas open to aquarium harvesting. 
cooperation with the Hawai'i Coral Reef Assessment and Monitoring Program (CRAMP) to estimate the abundance, diversity, and distribution of benthic habitats (see Brown et al. [2004], this volume).

The abundance of coral, nonliving substrates, and macroalgae was estimated at each site using a digital video camera (Sony DCRTRV900) in an underwater housing (Amphibico). In the laboratory, individual contiguous still frames from each transect were extracted from each video and archived on CD-ROM. Percentage cover estimates of substrate types were then obtained using the program PointCount '99 (P. Dustin, pers. comm.). PointCount projects a series of random dots on each image. An observer then identified the substratum type under each point. Abundance estimates of different substrate types were derived by examining the number of 50 points contacting each substrate within each video frame. Although as many as 40 frames were archived from some transects, we randomly selected 20 frames from each transect because this was a sufficient number of frames to detect a $10 \%$ change in mean coral cover between two surveys $(\alpha=\beta=$ $0.10)$. For this paper, habitat data were analyzed to test the assumption of our observational design that habitat variation was similar among FRA, reference, and open areas.

Survey methods were developed specifically for the monitoring of fishes and benthic substrates in West Hawaici. Fishes were surveyed using visual strip transects, which have been shown to be highly repeatable and reasonably accurate (Brock 1954, Sale 1980). Because strip transect counts are known to be biased by different observers (e.g., McCormick and Choat 1987), we created a transect design that would allow us to survey a single reference, FRA, and open area on a single day with the same set of observers. Thus, our transect design was constrained around a maximum total daily bottom time of $2.5 \mathrm{hr}$, or about $50 \mathrm{~min}$ per site. Other considerations that influenced our design were the variability of abundance estimates, the number of species sampled, and the statistical power to detect meaningful changes in fish abundance (Mapstone 1996).
Pilot studies on the design of optimal transect length and number were conducted at Māhukona, Hawai'i, during the final survey of the QUEST coral reef monitoring workshop in 1995, 1996, and 1997 (Hallacher and Tissot 1999). Each year, four 50-m transects were established at 7-m and $15-\mathrm{m}$ depths and all fishes were counted at $10-\mathrm{m}$ intervals along transects by a pair of divers. Sequential $10-\mathrm{m}$ segments of each transect were then pooled to examine the effects of various transect lengths on abundance estimates.

Based on species accumulation curves the number of different fish species observed along transects increased with transect length and number (Figure 2A). The number of species seen increased dramatically from 10 to 20-m transects, with smaller increases among 20-, 30-, 40-, and 50-m transect lengths. Based on these results, longer transects are likely to sample more species, although there did not appear to be much difference between results from 40- and 50-m transect lengths. In contrast, mean estimates of a common (yellow tang) and uncommon (Chaetodon quadrimaculatus) aquarium fish did not vary strongly with transect length, nor was there marked variation in the standard error of the estimate (Figure $2 B$ ). Thus, accuracy and precision did not appear to vary with transect length. Based on these two results, and the previously mentioned time constraints, we used a design that maximized the number of transects we could reasonably sample with two pairs of divers at a single site in 50 min: four $25-\mathrm{m}$ transects. Based on previous experience sampling coral reef fishes in Hawai' $i$ we selected a transect width of $2 \mathrm{~m}$, which has been shown to produce reasonably precise estimates of fish abundance in other areas (Sale and Sharp 1983, Cheal and Thompson 1997).

Power analysis of preliminary fish transect data indicated that our observational design would detect $10-160 \%$ changes in the abundance of the principal targeted aquarium fishes in West Hawai'i during the first year using reasonable error rates $(\alpha=\beta=0.10$; see Mapstone 1996). Power analyses were based on the ability of a two-sample $t$-test to detect significant differences between two 

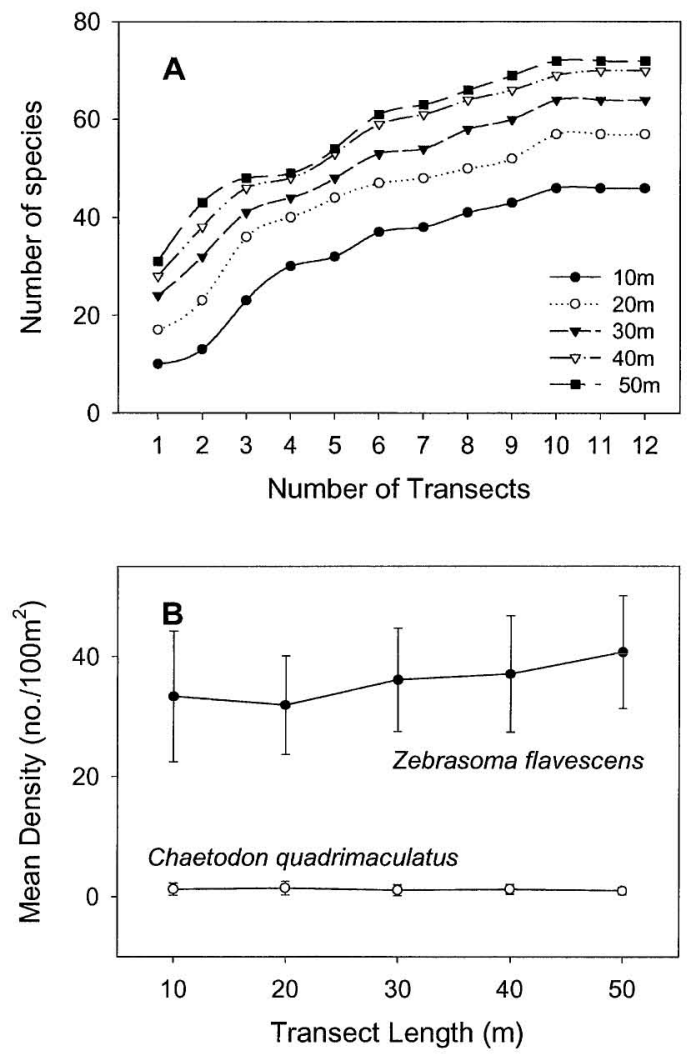

Figure 2. Results of pilot studies using visual strip transects that varied in transect length and number. $A$, Effects of various transect lengths and number on the total number of fish species observed. $B$, Effects of transect length on mean abundance and standard error of a common and an uncommon aquarium fish species.

samples. Our actual design is based on the BACI test (see under Data Analysis), which has even greater power to detect changes between surveys and locations (Underwood 1992).

Fish densities of all observed species were estimated by visual strip transect search along each permanent transect line. All divers either had extensive experience in conducting underwater fish surveys in Hawai'i or received training through QUEST before collecting any data. Two pairs of divers surveyed the lines, each pair searching two of the $25-\mathrm{m}$ lines in a single dive. The search of each line consisted of two divers, swimming side by side on each side of the line, surveying a column $2 \mathrm{~m}$ wide. On the outward-bound leg, larger planktivores and wide-ranging fishes within $4 \mathrm{~m}$ of the bottom were recorded. On the return leg, fishes closely associated with the bottom, new recruits, and fishes hiding in cracks and crevices were recorded. All sites were surveyed bimonthly, weather permitting, for a total of six surveys per year (five in 2000). Due to problems with our research vessel, surveys were not conducted during the summer of 2002.

\section{Data Analysis}

All fishes observed were categorized as follows: (1) high rates of aquarium collecting (10 spp.), (2) any aquarium collecting (an additional $47 \mathrm{spp}$.), and (3) nonaquarium species (152 spp.). The presence and extent of collecting was based on reports in Miyasaka (1997).

We predicted that the density of protected fishes should increase in FRAs after closure, relative to reference areas, due to cessation of collecting. We tested the significance of our predictions using the Before-After-Control Impact (BACI) procedure (Osenberg and Schmitt 1996). This method tested for significant change in fish density by comparing mean FRA-reference differences before closure with mean FRA-reference differences after closure. The same comparison was also made for changes in open-reference differences to examine changes outside the FRAs.

We conducted the BACI procedure using a one-way, repeated-measure analysis of variance (ANOVA) with data from baseline surveys in 1999 (surveys 1-6) and the last six surveys in 2002 (surveys 18-23) to estimate the effectiveness of the FRAs after $3 \mathrm{yr}$ of closure. Surveys were used as a random, repeated-measure factor. Data for the BACI analysis were limited to the five study areas that had reference, FRA, and open sites (Table 1). We evaluated effectiveness in two ways: (1) by calculating the percentage change in mean density from 1999 to 2002; and (2) by calculating the percentage change in the FRA-reference or open-reference difference from 1999 to 2002. 

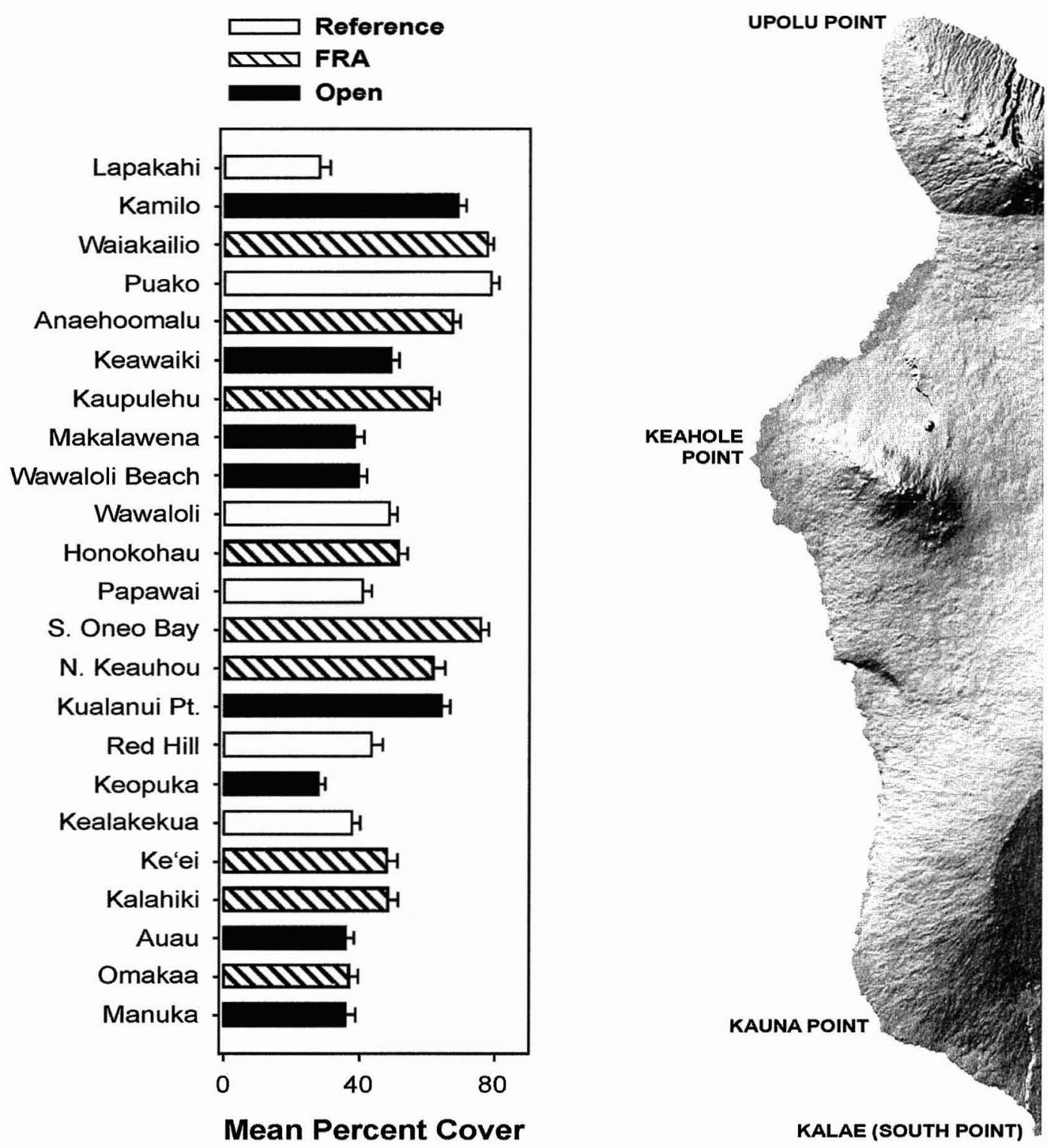

FIGURE 3. Mean percentage live coral cover at study sites in West Hawaici ( $\pm 1 \mathrm{SE}$ ). Site locations occur approximately opposite their geographic locations on the map (see Figure 1).

Estimates of the effects of aquarium collectors were made by comparing the mean density difference of target fishes in reference relative to FRA areas using the six baseline surveys from 1999 (see Tissot and Hallacher [2003] for a complete description of this method).
RESULTS

Benthic Habitat Analysis

Analysis of video transects revealed high variation in live coral cover in West Hawai' $i$ (Figure 3). Overall, mean percentage coral cover ranged between 27\% (Lapakahi) and 
TABLE 2

Effects of Aquarium Collecting on Nine Species Estimated by Mean Percentage FRA-Reference Area Differences Using Data from Surveys before FRA Closure ( $n=6$ surveys)

\begin{tabular}{lcc}
\hline \hline Taxa & $\begin{array}{c}\text { This } \\
\text { Study }\end{array}$ & $\begin{array}{c}\text { Tissot and } \\
\text { Hallacher (2003) }\end{array}$ \\
\hline Acantburus acbilles & $-56^{*}$ & $-58^{*}$ \\
Centropyge potteri & $-42^{*}$ & $-46^{*}$ \\
Chaetodon multicinctus & -4 & $-38^{*}$ \\
Chaetodon ornatissimus & -7 & $-39^{*}$ \\
Chaetodon quadrimaculatus & $-97^{*}$ & $-42^{*}$ \\
Ctenochaetus strigosus & $-14^{*}$ & -15 \\
Forcipiger spp. & $-55^{*}$ & $-54^{*}$ \\
Zanclus cornutus & $-49^{*}$ & $-46^{*}$ \\
Zebrasoma flavescens & $-43^{*}$ & $-47^{*}$ \\
Overall & $-26^{*}$ &
\end{tabular}

Note: Statistical differences in density between reference and FRA sites were tested using a two-sample $t$-test $\left(^{*}=\right.$ significant at $P<0.05)$. Mean estimates are compared with the study of Tissot and Hallacher (2003), which estimated the effects of aquarium collectors on these species in a previous study in West Hawai'i.

$78 \%$ (Puakō). In general, coral cover was higher in sheltered areas (e.g., Puakō) and lower in areas located on more wave-exposed headlands (e.g., Keōpuka). One-way ANOVA among coral cover at reference, FRA, and open areas was not significant $(F=2.18$; $\mathrm{df}=2,22 ; P=0.14)$.

\section{Effects of Collectors}

Overall, there were significantly less aquarium fishes in FRAs relative to reference areas in seven of the nine species analyzed during 1999 baseline surveys when collecting was still occurring (Table 2). Overall differences were significantly lower in Acantburus achilles (-56\%), Centropyge potteri (-42\%), Cbaetodon quadrimaculatus (-97\%), Ctenochaetus strigosus (-14\%), Forcipiger spp. (-55\%), Zanclus cornutus (-49\%), and Zebrasoma flavescens $(-43 \%)$. There were no significant differences in C. multicinctus or C. ornatissimus (Table 2). Overall, aquarium fishes were $26 \%$ less abundant in FRAs relative to reference areas.

\section{Effectiveness of FRAs}

Overall there was a significant increase in the abundance of aquarium fishes in FRAs after 2 yr of FRA closure (Table 3A). The mean density of aquarium fishes increased $26 \%$, and the mean density in FRAs relative to reference areas increased $50 \%$, between preand postclosure surveys (Figure 4). Two of the 10 aquarium species examined had significant increases in FRAs relative to reference areas: the yellow tang, Zebrasoma flavescens (74\%), and Potter's angelfish, Centropyge potteri $(80 \%)$. In contrast, there were no significant changes in nonaquarium fishes in FRAs (Table 3A, Figure 4).

In areas open to collecting there were no significant overall changes among aquarium nor nonaquarium fishes before and after FRA closure (Table 3B). However, two of the 10 aquarium species had significant increases in abundance in open relative to reference areas: Ctenochaetus strigosus (51\%) and Forcipinger flavissimus (61\%) (Table 3B).

\section{Recruitment}

Although newly recruited individuals were present during the summers of all years, there were higher levels of recruitment of aquarium fishes after FRA closure during the summers of 2001 and 2002 relative to earlier years (Figure 5). In contrast, nonaquarium recruits were more common in 1999 before FRA closure, declining in 2000-2002. A two-way BACI ANOVA was not significant among aquarium and nonaquarium recruits, before and after closure, nor was there a significant interaction between these two factors (all $P>0.05)$.

\section{DISCUSSION}

Analysis of baseline surveys in 1999 supports earlier research documenting significant effects of aquarium collector harvesting on selected fishes in West Hawai'i. Preclosure surveys indicate that collectors continued to target seven of the nine aquarium species examined in the FRAs before closure on 1 January 2000 . On average aquarium fishes were 
TABLE 3

Two-way BACI Repeated-Measure ANOVA Testing for Significant Changes in before (1999) and after (2002) FRA Closure (BA)

\begin{tabular}{|c|c|c|c|c|c|}
\hline \multirow[b]{2}{*}{ Taxa } & \multicolumn{2}{|c|}{$\begin{array}{l}\text { Mean Density } \\
\left(\mathrm{No} . / 100 \mathrm{~m}^{2}\right)\end{array}$} & \multirow{2}{*}{$\begin{array}{l}\text { \% Change } \\
\text { Density }\end{array}$} & \multirow{2}{*}{$\begin{array}{c}\text { \% FRA-Reference } \\
\text { Change }\end{array}$} & \multirow[b]{2}{*}{$P(\mathrm{BA})$} \\
\hline & Before & After & & & \\
\hline \multicolumn{6}{|l|}{ A. Reference-FRA differences } \\
\hline Acantburus acbilles & 0.22 & 0.28 & +27 & +13 & 0.76 \\
\hline Centropyge potteri & 1.16 & 1.03 & -17 & +80 & $0.03^{*}$ \\
\hline Chaetodon multicinctus & 4.88 & 3.92 & -20 & +76 & 0.26 \\
\hline Chaetodon ornatissimus & 0.95 & 0.91 & -4.2 & -112 & 0.75 \\
\hline Chaetodon quadrimaculatus & 0.01 & 0.02 & +100 & -61 & 0.08 \\
\hline Ctenocbaetus strigosus & 28.1 & 32.3 & +15 & +29 & 0.40 \\
\hline Forcipiger flavissimus & 0.61 & 0.44 & -28 & +49 & 0.34 \\
\hline Forcipiger longirostris & 0.27 & 0.45 & +67 & -47 & 0.32 \\
\hline Zanclus cornutus & 0.27 & 0.13 & -52 & +27 & 0.57 \\
\hline Zebrasoma flavescens & 14.2 & 24.6 & +73 & +74 & $<0.01^{*}$ \\
\hline All aquarium fishes & 50.6 & 64.0 & +26 & +50 & $0.01^{*}$ \\
\hline All nonaquarium fishes & 42.1 & 47.2 & +12 & -27 & 0.12 \\
\hline \multicolumn{6}{|l|}{ B. Reference-open differences } \\
\hline Acantburus achilles & 0.53 & 0.46 & -13 & +131 & 0.15 \\
\hline Centropyge potteri & 1.62 & 1.43 & -12 & +161 & 0.06 \\
\hline Chaetodon multicinctus & 4.70 & 4.22 & -11 & -44 & 0.86 \\
\hline Chaetodon ornatissimus & 0.72 & 0.67 & -6.9 & -37 & 0.60 \\
\hline Chaetodon quadrimaculatus & 0.53 & 0.51 & -3.8 & -127 & 0.23 \\
\hline Ctenocbaetus strigosus & 22.4 & 30.5 & +36 & +51 & $<0.01^{*}$ \\
\hline Forcipiger flavissimus & 0.46 & 0.45 & -2.2 & +61 & $0.01^{*}$ \\
\hline Forcipiger longirostris & 0.36 & 0.49 & +36 & -72 & 0.32 \\
\hline Zanclus cornutus & 0.35 & 0.44 & +26 & +167 & 0.06 \\
\hline Zebrasoma flavescens & 13.7 & 13.8 & +0.7 & -21 & 0.16 \\
\hline All aquarium fishes & 45.0 & 52.8 & +17 & +14 & 0.11 \\
\hline All nonaquarium fishes & 60.8 & 74.8 & +23 & +0.7 & 0.94 \\
\hline
\end{tabular}

Note: $P$ values are reported for the most commonly targeted aquarium fishes, all aquarium species pooled $(n=57$ species), and nonaquarium species ${ }^{*}=$ significant at $P<0.05$ ).

14-97\% less abundant, and overall 26\% less abundant in FRAs than in adjacent reference areas. With the exception of $C$. multicinctus and $C$. ornatissimus, these estimates are remarkably similar to those reported previously by Tissot and Hallacher (2003), whose study was conducted in 1997-1998 at two of the nine areas surveyed in this study.

Three years after closure of FRAs there were significant increases in the overall abundance of fishes targeted by collectors. It is interesting that the estimated increase in abundance $(26 \%)$ is the same amount as the estimated reduction due to collectors before FRA closure, suggesting that as a group these fishes may have increased to their preexploi- tation levels. However, only two species, the yellow tang and Potter's angelfish, showed significant (74-80\%) increases in FRAs relative to previously protected reference areas. Moreover, several others species, notably $C$. multicinctus and $F$. flavissimus, showed high (>40\%) but nonsignificant increases in FRAs relative to reference area (Table 3 ), and several other species (C. ornatissimus, $C$. quadrimaculatus, and $F$. longirostris) showed high but nonsignificant decreases in FRAs relative to reference areas. Thus, because Potter's angelfish is not abundant, it seems likely that the significant increase in aquarium fishes was largely driven by the dramatic increase in yellow tangs to preexploitation (or reference) 

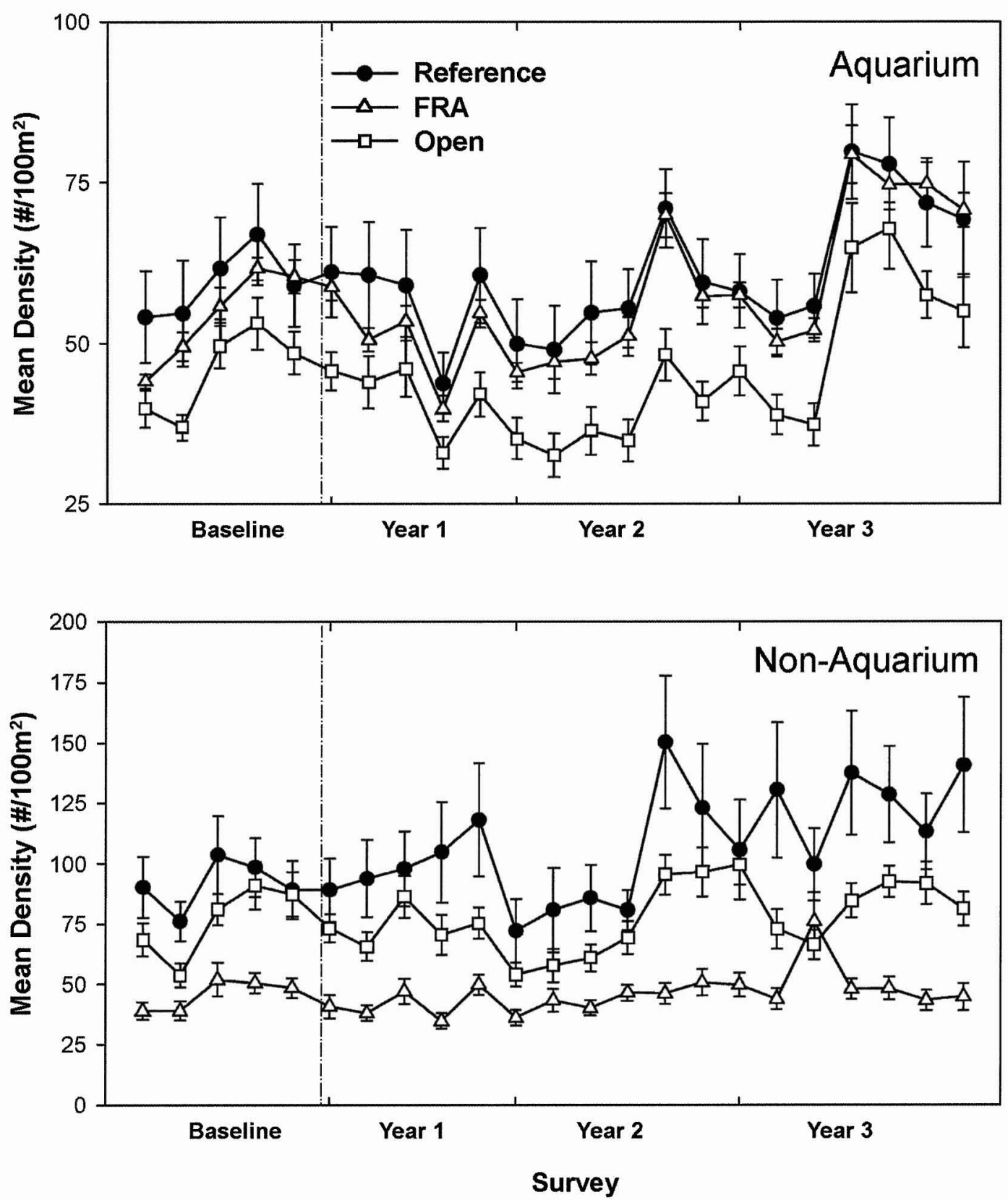

FIgURE 4. Changes in mean density of fishes in reference, open, and FRA areas pooled across all surveys before and after FRA closure ( $\pm 1 \mathrm{SE})$. Top: aquarium fishes; bottom: nonaquarium fishes. 

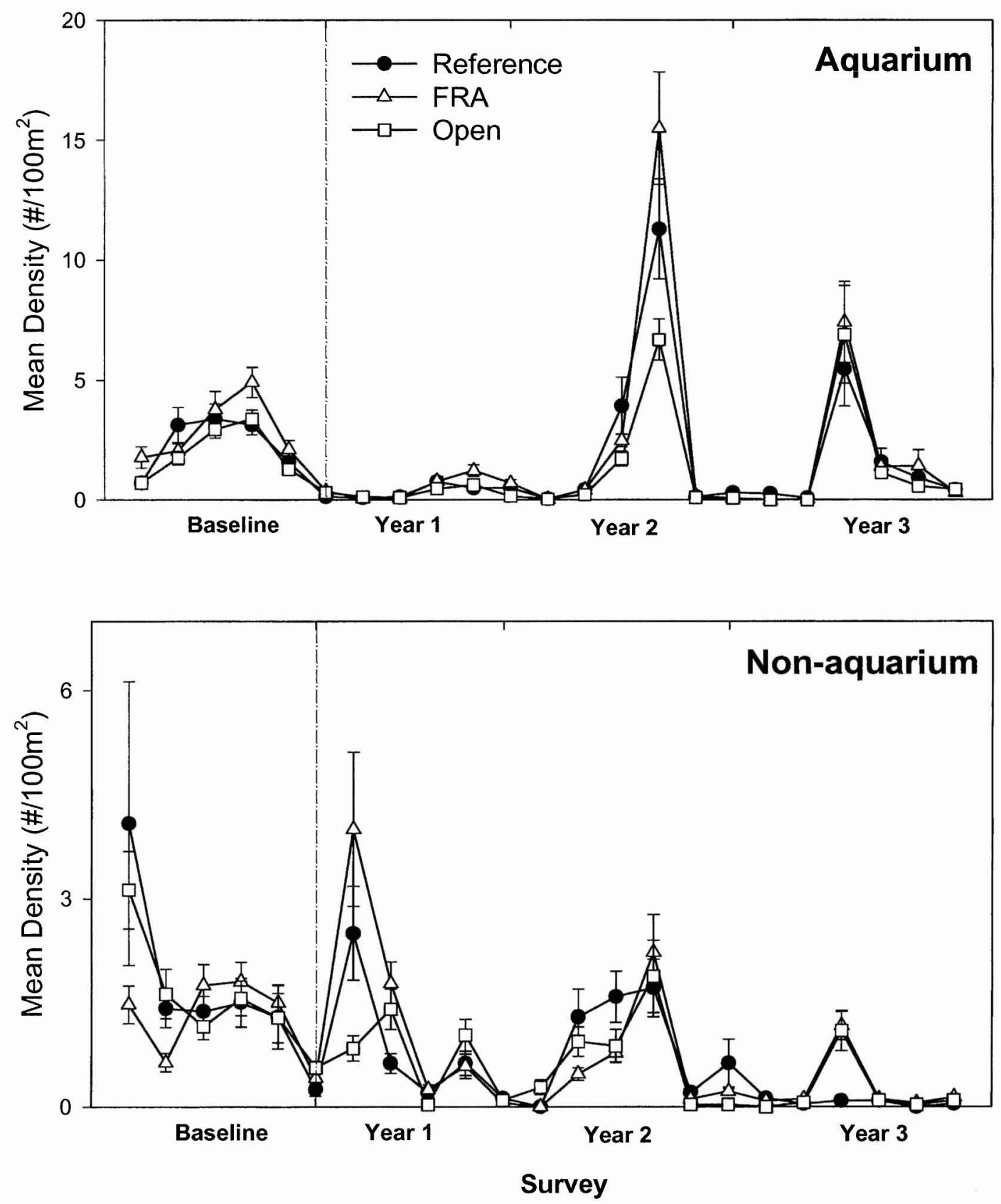

FIGURE 5. Changes in mean density of newly recruited fishes in reference, open, and FRA areas pooled across all surveys before and after FRA closure $( \pm 1 \mathrm{SE})$. Top: aquarium fishes; bottom: nonaquarium fishes. 
levels. This observation is supported by the fact that the yellow tang composes about $82 \%$ of the total aquarium catch in West Hawai' $i$ (Miyasaka 1997).

In contrast, there were no significant changes among noncollected species within FRAs or in aquarium and nonaquarium species in areas outside FRAs. Furthermore, no aquarium fishes declined in abundance in open areas as might be expected if the intensity of harvest increased outside the FRAs. In fact, two species displayed significant increases in abundance. Thus, overall the results of this study indicate that FRAs can help aquarium fish recover abundance, at least for the yellow tang and Potter's angelfish, without associated decreases in abundance outside FRAs, a common criticism of MPAs (e.g., Chapman and Kramer 1999).

There was strong interannual variation in the abundance of newly recruiting fishes in West Hawai'i. In general nonaquarium species had higher rates of recruitment before FRAs were closed in 1999, whereas aquarium species had higher recruitment in 2001 and 2002, after closure. It should be noted that the 2002 recruitment event of aquarium fishes was much larger than in 2001; the low number in the data is due to the fact that no surveys were conducted during the main summer months of 2002, only in September. Thus, it is tempting to associate the recovery of aquarium fishes in FRAs with high rates of recruitment, suggesting that the FRAs are enhancing recruitment. However, there was no significant variation between newly recruiting aquarium and nonaquarium fishes before or after FRA closure, and similar high temporal variation in reef fish recruitment in West Hawai' $i$ was observed by Walsh (1987) over a 5 -yr period. Thus, significant recovery in FRAs in some species during high levels of recruitment in 2001-2002 indicates that the frequency of recruitment is likely to be an important mechanism replenishing depleted stocks within MPAs in Hawai'i.

The results of this study demonstrate that the MPAs can effectively promote recovery of fish stocks depleted by fishing pressures in Hawai'i, at least in heavily exploited species, without significant declines outside MPAs.
Within 3 yr two species, the yellow tang and Potter's angelfish, both reduced by over $40 \%$ before protection, displayed significant increases inside FRAs relative to reference areas. Yellow tangs increased in density $73 \%$ between 1999 and 2002, or about 10.4 fish per $100 \mathrm{~m}^{2}$.

Based on these results it would be prudent to establish additional MPAs throughout $\mathrm{Ha}-$ wai' $i$ as a precautionary measure against overfishing of marine resources. Currently, less than $1 \%$ of the main Hawaiian Islands is protected by MPAs (Clark and Gulko 1999). Furthermore, because recruitment appears to be an important mechanism influencing the replenishment of nearshore populations, we also advocate for increased monitoring of recruitment and nearshore oceanography to help better understand the dynamics of recruitment processes.

\section{ACKNOWLEDGMENTS}

For logistical support we thank Brent Carmen, Robert Nishimoto, Steve Cotton, John Coney, and Sara Peck. The fieldwork was supported by students at the University of Hawai'i at Hilo, including Steve Cotton, Anne Creason, Kathy Greenwood, Ranya Henson, Shaun Norris, Greg Polloi, Linda Preskitt, Noelani Puniwai, Dan VanRavenswaay, Lisa Wedding, Darla White, and Brian Zgliczynski. Jonathan Hultquist and Anne Creason conducted the PointCount analysis and Kathy Greenwood assisted in data entry. The manuscript was improved by the comments of two anonymous reviewers.

\section{Literature Cited}

Allison, G. W., J. Lubchenco, and M. H. Carr. 1998. Marine reserves are necessary but not sufficient for marine conservation. Ecol. Appl. 8 (1): S79-S92.

Aronson, R. B., P. J. Edmunds, W. F. Precht, D. W. Swanson, and D. R. Levitan. 1994. Large-scale, long-term monitoring of Caribbean coral reefs: Simple, quick, inexpensive techniques. Atoll Res. Bull. 421: 1-19. 
Bohnsack, J. A. 1998. Application of marine reserves to reef fisheries management. Aust. J. Ecol. 23:298-304.

Brock, V. E. 1954. A preliminary report on a method of sampling fish populations. J. Wildl. Manage. 18:297-308.

Brown, E., E. Cox, P. Jokiel, K. Rodgers, W. Smith, B. Tissot, S. L. Coles, and J. Hultquist. 2004. Development of benthic sampling methods for the Coral Reef Assessment and Monitoring Program (CRAMP) in Hawai'i. Pac. Sci. 58:145158.

Carleton, J. H., and T. J. Done. 1995. Quantitative video sampling of coral reef benthos: Large-scale application. Coral Reefs 14:35-46.

Chapman, M. R., and D. L. Kramer. 1999. Gradients in coral reef fish diversity and size across the Barbados Marine Reserve boundary: Effects of reserve protection and habitat characteristics. Mar. Ecol. Prog. Ser. 181:81-96.

Cheal, A. J., and A. A. Thompson. 1997. Comparing visual counts of coral reef fish: Implications of transect width and species selection. Mar. Ecol. Prog. Ser. 158:241248.

Clark, A. M., and D. A. Gulko. 1999. Hawai'i's state of the reefs report, 1998. State of Hawai' $i$ Department of Land and Natural Resources, Honolulu.

Dollar, S. J. 1982. Wave stress and coral community structure in Hawaii. Coral Reefs 1:71-81.

Grigg, R. W. 1997. Hawaii's coral reefs: Status and health in 1997, the International Year of the Reef. Pages 59-72 in R. W. Grigg and C. Birkeland, eds. Status of coral reefs in the Pacific. University of Hawai'i Sea Grant College Program, Honolulu.

Grigg, R. W., and J. E. Maragos. 1974. Recolonization of hermatypic corals on submerged lava flows in Hawaii. Ecology 55:387-395.

Hallacher, L. E., and B. N. Tissot. 1999. QUEST: Quantitative Underwater Ecological Survey Techniques: A coral reef monitoring workshop. Proceedings of the Hawai'i Coral Reef Monitoring Work- shop, Department of Land and Natural Resources, Honolulu, Hawai'i.

Mapstone, B. 1996. Scalable decision criteria for environmental impact assessment: Effect size, Type I, and Type II errors. Pages 67-79 in R. J. Schmitt and C. W. Osenberg, eds. Detecting ecological impacts: Concepts and applications in coastal habitats. Academic Press, San Diego.

McCormick, M. I., and J. H. Choat. 1987. Estimating total abundance of a large temperate-reef fish using visual striptransects. Mar. Biol. (Berl.) 96:469-478.

Miyasaka, A. 1997. Status report, aquarium fish collections, fiscal year 1994-95. Division of Aquatic Resources, Department of Land and Natural Resources, Honolulu.

Murray, S., R. F. Ambrose, J. A. Bohnsack, L. W. Botsford, M. H. Carr, G. E. Davis, P. K. Dayton, D. Gotshall, D. R. Gunderson, M. A. Hixon, J. Lubchenco, M. Mangel, A. MacCall, D. A. McArdle, J. C. Ogden, J. Roughgarden, R. M. Starr, M. J. Tegner, and M. M. Yoklavich. 1999. No-take reserve networks: Sustaining fishery populations and marine ecosystems. Fisheries (Bethesda) 24 (11): $11-25$.

Osenberg, C. W., and R. J. Schmitt. 1996. Detecting ecological impacts caused by human activities. Pages 3-16 in R. J. Schmitt and C. W. Osenberg, eds. Detecting ecological impacts: Concepts and applications in coastal habitats. Academic Press, San Diego.

Richmond, R. H. 1993. Coral reefs: Present problems and future concerns resulting from anthropogenic disturbance. Am. Zool. 33:524-536.

Sale, P. F. 1980. The ecology of fishes on coral reefs. Oceanogr. Mar. Biol. Annu. Rev. 18:367-421.

Sale, P. F., and W. A. Douglas. 1981. Precision and accuracy of visual census technique for fish assemblages on coral patch reefs. Environ. Biol. Fishes 6 (3/4): 333339.

Sale, P. F., and B. J. Sharp. 1983. Correcting for bias in visual transect censuses of coral reef fishes. Coral Reefs 2:37-42.

Tissot, B. N., and L. E. Hallacher. 2003. Ef- 
fects of aquarium collectors on reef fishes in Kona, Hawai'i. Conserv. Biol. 17 (6): 1759-1768.

Underwood, A. J. 1992. Beyond BACI: The detection of environmental impacts on populations in the real, but variable, world. J. Exp. Mar. Biol. Ecol. 161:145-178.

Walsh, W. J. 1987. Patterns of recruitment and spawning in Hawaiian reef fishes. Environ. Biol. Fishes 18 (4): 257-276. 